\title{
UJI VALIDASI ISI MODUL PSIKOEDUKASI TUTORIAL MEMBACA PERMULAAN UNTUK GURU SEKOLAH DASAR
}

\section{CONTENT VALIDATION TEST OF THE PSIKOEDUKASI TUTORIAL MEMBACA PERMULAAN MODULE FOR ELEMENTARY SCHOOL TEACHER}

\author{
Nanda Yunika Wulandari \\ Universitas Mercu Buana Yogyakarta \\ nanda@mercubuana-yogya.ac.id
}

\begin{abstract}
Abstrak
Salah satu cara yang terbukti dapat meningkatkan kemampuan membaca siswa adalah tutorial membaca menggunakan Reading Recovery. Untuk memiliki kemampuan yang mencukupi dalam memberikan tutorial membaca, maka guru membutuhkan rangkaian program pelatihan yang spesifik dan terukur. Penelitian ini bertujuan untuk membuat dan melakukan proses validasi isi modul "Psikoedukasi Tutorial Membaca Permulaan" dengan model pembelajaran experiential learning untuk meningkatkan pengetahuan dan keterampilan guru dalam pemberian tutorial membaca menggunakan reading recovery oleh guru Sekolah Dasar. Pada penelitian ini akan dipaparkan mengenai uji validasi isi modul tersebut. Validasi isi dilakukan dengan menggunakan professional Judgement oleh 7 orang profesional yang terdiri dari praktisi, yaitu; psikolog sekolah, kepala sekolah dan guru senior serta akademisi, yaitu; dosen psikologi dan dosen PGSD. Hasil analisa Aiken's V terhadap masing-masing aspek menunjukan skor $\mathrm{V}$ antara 0,75 - 0,91. Adapun validitas isi keseluruhan modul menggunakan prosentase menunjukan hasil sebesar $87,32 \%$ artinya modul memiliki validitas isi yang baik dan dapat digunakan untuk tahap selanjutnya, yaitu uji empiris.
\end{abstract}

Kata Kunci: modul tutorial membaca, validasi isi, experiential learning

\begin{abstract}
One of the ways proven to increase students' reading ability was a reading tutorial using Reading Recovery. In order to have sufficient ability to provide a reading tutorial, the teachers need a series of a specific and measurable training program. This study aims to create and validate the contents of the "Psikoedukasi Tutorial M embaca Permulaan" (Psychoeducation Beginner Reading Tutorial) module with experiential learning model in improving teachers' knowledge and skills in giving the tutorial of reading using reading recovery by elementary school teachers. This study will explain the validation test of the content of the module. This study will explain the content validation of the module. It was tested by 7 professional judgment consist of practitioners, namely; school psychologist, principal, senior teachers, and academicians, namely; psychology professor and lecturer of Primary School Teacher Education. The results of the analysis of Aiken's $V$ towards each $V$ aspect showed scores between 0.75 to 0.91. As for the overall validity of the content module using percentages shows the results of $87.32 \%$, it means that the module has a good content validity and can be used for the next stage, the empirical test.
\end{abstract}

Keywords: reading tutorial modules, content validity, experiential learning 


\section{PENDAHULUAN}

Di Indonesia masih banyak siswa terindikasi mengalami kesulitan membaca. Berdasarkan survei awal yang dilakukan peneliti di wilayah kecamatan Jetis, kabupaten Bantul pada tanggal 29 - 21 September 2016 kepada 67 guru didapatkan hasil yaitu sebanyak 98,5\% atau 66 orang menyatakan bahwa guru mendapati siswa yang memiliki kesulitan membaca di kelas. Sebanyak 56 dari 67 responden menyebutkan bahwa mereka menemukan siswa dengan ketidaklancaran membaca ketika mengajar di kelas I dan II.

Perbedaan kemampuan siswa dalam menerima materi pembelajaran seperti yang telah terpapar pada data di atas menyebabkan perlunya dukungan khusus untuk membantu siswa meningkatkan kemampuan sesuai dengan kebutuhan masing-masing (Gustafson, Falth, Svensson, Tjus \& Heimann, 2011; Ormord, 2008). Guru dapat berperan dalam meningkatkan kemampuan siswanya. Guru yang memiliki pengetahuan dan keterampilan yang baik akan mendukung kesuksesan suatu program pembelajaran (Winter dalam Woodcock, 2013).

Carta, Greenwood, Atwater, McConnell, Goldstein, \& Kaminski (2015) dalam penelitiannya menyebutkan bahwa keberagaman kemampuan membaca yang dialami oleh para siswa cenderung kurang mendapat perhatian khusus dari guru kelas, terutama di kelas I. Berdasarkan survey elektronik yang disebar 9 - 21 November 2015 didapatkan hasil bahwa terdapat perbedaan perlakuan yang diberikan antara guru yang telah memiliki pengetahuan dan keterampilan mengenai tutorial membaca dengan yang belum memiliki pengetahuan dan keterampilan mengenai program tutorial membaca. Hal tersebut juga diperkuat dengan data wawancara terhadap dua orang guru yang bertugas di sekolah dasar negeri di wilayah Bantul dan kota Yogyakarta. Dari data survey elektronik maupun wawancara tersebut didapatkan kesimpulan bahwa guru yang tidak memiliki pengetahuan maupun keterampilan mengenai tutorial membaca cenderung tidak melakukan pendampingan khusus kepada siswa yang diduga mengalami kesulitan membaca.

Keterbatasan pengetahuan terkait pemberian intervensi yang sesuai untuk siswa dengan kesulitan belajar menyebabkan guru tidak memberikan perlakuan khusus terhadap siswa tersebut. Guru cenderung memperlakukan siswa yang diindikasi mengalami kesulitan belajar seperti siswa pada umumnya (Woodcock \& Vialle, 2011). Fakta tersebut diperkuat dalam hasil penelitian Kumaladewi (2011) yang memaparkan bahwa guru menganggap siswa di kelas I dan II yang mengalami permasalahan membaca seperti belum lancar membaca adalah hal yang wajar. Guru cenderung akan mempermasalahkan siswa yang belum dapat memahami bacaan yang dibacanya apabila siswa tersebut telah berada di kelas yang lebih tinggi, yaitu berada di kelas III - V. Berdasarkan pemaparan tersebut, dapat 
diambil kesimpulan bahwa terdapat guru di kelas I dan II belum memiliki pengetahuan yang memadai mengenai kemampuan membaca pada anak. Guru juga belum memiliki keterampilan mengajar tutorial membaca yang memadai untuk meningkatkan kemampuan membaca siswa yang diindikasi mengalami masalah membaca.

Woolfolk-Hoy \& Spero (2005) menyebutkan bahwa membedakan perlakuan terhadap siswa yang mengalami kesulitan belajar bukan merupakan suatu keterampilan yang mudah dan dapat langsung dilakukan oleh guru pada umumnya. Sayangnya, pemberian pengetahuan dan keterampilan dalam menangani anak dengan kesulitan membaca masih terbatas. Survei elektronik disebar pertama kali pada tanggal 9 hingga 21 November 2015 terdapat 76 responden mengisi survei. Dari survei yang disebar diperoleh hasil bahwa terdapat 50 dari 76 orang guru atau $66 \%$ dari total responden yang belum mendapatkan pelatihan tutorial membaca. Dari pemaparan di atas dapat disimpulkan bahwa guru membutuhkan program pelatihan khusus untuk meningkatkan pengetahuan dan keterampilan dalam melakukan tutorial membaca kepada siswa.

Program pelatihan khusus yang ditujukan untuk meningkatkan pengetahuan dan keterampilan guru mengenai tutorial membaca permulaan disusun menjadi sebuah paket modul untuk dapat diuji sehingga dapat diterapkan sesuai dengan tujuan. Modul merupakan paket pembelajaran yang memuat sebuah konsep atau materi (Russell dan Johanningsmeier, 1981; Ahmad, Sulaiman, Abdullah, Shamsuddin, 2009). Materi yang disusun dan digunakan dalam modul ini terdiri dari lima materi pokok menurut Florida Center for Reading Research dalam pemberian pelatihan guru mengenai tutorial membaca yaitu pengetahuan tentang anak dan tahapan perkembangan membaca, permasalahan membaca pada anak, peran yang dapat dilakukan guru untuk meningkatkan kemampuan membaca, cara untuk mengidentifikasi kemampuan membaca siswa, dan pengetahuan mengenai langkah-langkah tutorial membaca. Dengan mengacu pada materi pokok diatas maka peneliti membuat dan menyusun rangkaian program pelatihan dalam bentuk paket pembelajaran dengan judul "Modul Psikoedukasi Tutorial Membaca Permulaan untuk Guru Sekolah Dasar".

Proses belajar dalam modul psikoedukasi yang digunakan dalam penelitian ini berdasar pada teori experiential learning yang dikemukakan oleh Kolb (McCarthy, 2010). Experiential learning merupakan model proses belajar mengajar dengan cara menempatkan pembelajar sebagai sosok yang aktif dalam membangun pengetahuan dan keterampilan melalui pengalaman langsung (Majid, 2013; Malcom Knowles dalam Hamdani, 2011; Tomkins \& Ulus, 2015). Alasan digunakan Experiential Learning sebagai proses belajar adalah model pembelajaran tersebut memiliki prinsip-prinsip belajar bagi orang dewasa 
(andragogi) dan guru yang menjadi subjek penelitian ini adalah orang dewasa. Terdapat empat tahapan yang akan dialami oleh peserta pada setiap sesi psikoedukasi. Tahapantahapan tersebut adalah tahap pengalaman nyata (concrete experience), tahap observasi refleksi (reflective observation), tahap konseptualisasi (abstract conceptualization), dan tahap implementasi (active experimentation) (Holman, Pavlica, \& Thorpe, 1997).

Modul adalah paket pembelajaran yang memuat sebuah konsep atau materi (Russell dan Johanningsmeier, 1981; Ahmad, Sulaiman, Abdullah, Shamsuddin, 2009). Guna membuktikan apakah modul yang disusun telah sesuai dengan tujuan pembuatan, maka diperlukan serangkaian proses uji terhadap modul tersebut. Russell \& Johanningsmeier (1981) menjabarkan bahwa terdapat enam langkah dalam penyusunan desain, pengembangan dan validasi sebuah modul pembelajaran. Keenam langkah tersebut adalah: (1) Tujuan atau sasaran modul yang spesifik; (2) Alat ukur kompetensi yang sesuai; (3) Karakteristik subjek; (4) Disain dan metode pembelajaran; (5) Percobaan kepada subjek; dan (6) Evaluasi proses pembelajaran. Validasi isi merupakan bagian dari tahap keempat dalam penyusunan desain, pengembangan dan validasi sebuah modul pembelajaran menurut Russel dan Johanningsmeier (1981).

Tujuan dari penelitian ini adalah membuat desain dan metode pembelajaran yang diwujudkan dalam bentuk modul dan memvalidasi isi sebuah modul psikoedukasi pelatihan yang pada tahap penelitian selanjutnya dapat diujikan untuk meningkatkan pengetahuan dan keterampilan guru Sekolah Dasar mengenai program tutorial membaca.

\section{METODE}

Modul psikoedukasi tutorial membaca permulaan disusun oleh peneliti dengan mengacu pada lima materi pokok menurut Florida Center for Reading Research dalam pemberian pelatihan guru mengenai tutorial membaca. Modul dibuat berisi materi mengenai tahapan perkembangan membaca pada anak, mengidentifikasi kemampuan membaca, menjadi tutor yang menyenangkan, pengertian tutorial membaca dan simulasi mengajar tutorial menggunakan Reading Recovery.

Materi pada modul psikoedukasi yang disusun terbagi menjadi delapan sesi dengan total durasi waktu pelatihan adalah 12 jam. Seluruh prosedur pelaksanaan program dilaksanakan selama dua kali pertemuan dan dilakukan di dalam ruangan (indoor activity). Setiap sesi pada modul dilaksanakan melalui model pembelajaran Experiential Learning menurut Kolb yang terdiri atas empat siklus yaitu; concrete experience, reflective observation, abstract conceptualization, dan active experimentation (Holman dkk, 1997). 
Penelitian ini melakukan studi deskriptif mengenai modul yang dibuat dengan melakukan uji validitas isi pada modul tutorial membaca permulaan. Uji validitas isi/ konten dilakukan dengan melibatkan ahli yang berkompeten pada bidang yang diteliti (Arip, Bakar, Ahmad \& Jais, 2013) yang disebut sebagai professional judgment (Supraktiknya, 2014). Pada penelitian ini terdapat 7 orang professional judgment untuk melihat dan memberikan penilaian terkait konsep, prinsip dan teknik yang diberikan dalam modul apakah sesuai dengan tujuan yang dibuat. Ketujuh ahli tersebut dipilih berdasarkan minat, kompetensi, pengalaman pada bidang pendampingan membaca dan pelatihan pada orang dewasa.

\section{HASIL DAN PEMBAHASAN}

Terdapat dua kriteria penting dalam proses pengembangan sebuah modul, yakni validasi isi dan manfaat modul setelah di uji cobakan (Noah \& Ahmad dalam Rozubi \& Li, 2015; Sugiyono, 2015). Russel \& Johanningsmeier (1981) menyatakan bahwa dalam pembuatan suatu modul diperlukan proses validasi isi dan uji coba terbatas dengan subjek nyata. Penelitian ini berfokus pada uji validasi isi modul sebelum di uji cobakan pada subjek nyata.

Hasil penelitian dihitung menggunakan formula aiken's $\mathrm{V}$ untuk menghitung koefisien validitas isi pada masing-masing sesi. Berikut ini merupakan hasil validasi isi pada masingmasing aspek menggunakan perhitungan aiken's V:

Tabel 1. Hasil Validitas Isi modul "Tutorial Membaca” menggunakan Aiken's V untuk masing-masing sesi

\begin{tabular}{clc}
\hline No. & \multicolumn{1}{c}{ Sesi } & $\begin{array}{c}\text { Koefisien } \\
\text { Validitas }\end{array}$ \\
\hline 1 & Orientasi Program & 0,91 \\
2 & Anak dan Tahapan Perkembangan Membaca & 0,785 \\
3 & Permasalahan membaca \& penyebab & 0,821 \\
4 & Menjadi tutor yang TKP & 0,857 \\
5 & Identifikasi kemampuan membaca & 0,75 \\
6 & Program Tutorial Membaca & 0,892 \\
7 & Simulasi Mengajar Tutorial & 0,857 \\
8 & Penutupan & 0,857 \\
\hline
\end{tabular}

Berdasarkan kriteria penilaian mengunakan indeks $\mathrm{V}$ yang menyatakan bahwa hasil validasi yang memperoleh skor antara 0,75 - 0,91 maka dapat disimpulkan bahwa semua sesi pada modul pelatihan "Tutorial Membaca Permulaan" memiliki validitas isi yang baik dan dapat digunakan. 
Tabel 2. Hasil perhitungan Validasi isi modul

\begin{tabular}{lccccccc}
\hline \multirow{2}{*}{ Sesi } & \multicolumn{7}{c}{ Penilaian dari ahlli } \\
\cline { 2 - 8 } & A & B & C & D & E & F & G \\
\hline I (Orientasi Program) & 5 & 5 & 4 & 4 & 5 & 5 & 4,5 \\
II (Anak dan Tahapan Perkembangan Membaca) & 4 & 3 & 4 & 4 & 5 & 4,5 & 4,5 \\
III (Permasalahan membaca \& penyebab) & 4 & 4 & 4 & 4 & 4 & 5 & 5 \\
IV (Menjadi tutor yang TKP) & 4 & 4 & 4 & 5 & 4 & 5 & 5 \\
V (Identifikasi kemampuan membaca) & 4 & 4 & 4 & 5 & 3 & 4 & 4 \\
VI (Program Tutorial Membaca) & 4 & 4 & 5 & 4 & 5 & 5 & 5 \\
VII (Simulasi Mengajar Tutorial) & 4 & 4 & 4 & 4 & 5 & 5 & 5 \\
VIII (Penutupan) & 4 & 4 & 4 & 4 & 5 & 5 & 5 \\
\hline JUMLAH & $\mathbf{3 3}$ & $\mathbf{3 2}$ & $\mathbf{3 3}$ & $\mathbf{3 4}$ & $\mathbf{3 6}$ & $\mathbf{3 8 , 5}$ & $\mathbf{3 8}$ \\
\hline
\end{tabular}

Tabel 3. Hasil Validasi keseluruhan Isi Modul "Tutorial Membaca" menggunakan prosentase

\begin{tabular}{cccc}
\hline No. & Ahli & Prosentase Penilaian & Keterangan \\
\hline 1 & A & $82,50 \%$ & Layak \\
2 & B & $80,00 \%$ & Layak \\
3 & C & $82,50 \%$ & Layak \\
4 & D & $85,00 \%$ & Sangat layak \\
5 & E & $90,00 \%$ & Sangat layak \\
6 & F & $96,50 \%$ & Sangat layak \\
7 & G & $95,00 \%$ & Sangat layak \\
\hline \multicolumn{2}{r}{ Rata-rata } & $\mathbf{8 7 , 3 2 \%} \%$ & Sangat layak \\
\hline
\end{tabular}

Untuk memberikan penilaian validitas keseluruhan modul, data mentah dihitung dengan menggunakan rumus: skor total yang diberikan oleh seorang pakar (x) dibagi keseluruhan skor (y). Hasil dari perhitungan tersebut merupakan hasil validasi dari modul penelitian. Hasil validasi isi keseluruhan isi modul menggunakan prosentase adalah 87,32 \%. Berdasarkan kriteria kelayakan hasil validasi oleh Slavin (Ayriza, 2008; Arip dkk, 2013) menyatakan bahwa hasil validasi yang memperoleh skor 70\%-84\% berada pada kriteraia layak, dan skor $85 \%-100 \%$ berada pada kriteria sangat layak, maka dapat disimpulkan secara keseluruhan modul pelatihan "Tutorial Membaca Permulaan" memiliki validitas isi yang baik dan dapat digunakan.

Modul merupakan suatu paket pembelajaran yang memuat sebuah konsep atau materi (Russell dan Johanningsmeier, 1981). Tujuan dari penelitian ini adalah untuk menyusun dan memvalidasi ini sebuah modul psikoedukasi pelatihan yang pada tahap selanjutnya dapat digunakan untuk meningkatkan keterampilan guru Sekolah Dasar mengenai program tutorial membaca permulaan. Modul yang baik adalah modul yang memiliki validitas isi yang baik (Russell \& Johanningsmeier, 1981; Ahmad dkk., 2008). Adapun yang dimaksud validitas isi 
dalam penelitian ini mengacu pada kesesuaian modul dengan konten yang seharusnya ada dalam modul tersebut.

Validitas modul psikoedukasi tutorial membaca permulaan untuk guru pada masingmasing sesi maupun keseluruhan menunujukan hasil yang baik. Nilai koefisien validitas modul dilihat dari masing-masing sesi bergerak antara 0,75 - 0,91. Azwar (2012) menyatakan bahwa nilai koefisien validitas 0,5 dapat diterima dan dianggap memuaskan. Adapun validitas isi keseluruhan modul diperoleh prosentase $87,32 \%$. Validasi isi dapat dikategorikan tinggi apabila memiliki nilai prosentase diatas $70 \%$ (Ayriza, 2008; Tuckman \& Waheed dalam Arip dkk, 2013). Artinya validitas isi modul psikoedukasi tutorial membaca permulaan tergolong baik serta terdapat kesesuaian antara materi yang ada dalam modul dengan tujuan pembuatan modul.

Perolehan skor validasi isi modul tersebut dipengaruhi oleh langkah-langkah yang dilakukan oleh peneliti dalam menyusun modul. Russell dan Johaningsmeier (1981) memaparkan terdapat enam langkah yang saling terkait dalam penyusunan desain, pengembangan, dan validasi modul pembelajaran. Keenam langkah tersebut adalah menentukan tujuan atau sasaran modul secara spesifik, alat ukur kompetensi yang sesuai, menentukan karakteristik subjek, membuat desain dan metode pembelajaran, melakukan percobaan pada subjek dan evaluasi proses pembelajaran. Penyusunan modul psikoedukasi tutorial membaca permulaan untuk guru SD merujuk pada langkah pertama hingga keempat penyusunan modul pembelajaran menurut Russell dan Johanningsmeier.

\section{KESIMPULAN}

Penelitian ini berhasil memberikan kontribusi dalam membuat suatu modul yang valid, dilihat dari segi isi untuk kemudian dapat diterapkan kepada guru untuk di ujikan di seting nyata. Pada tahap selanjutnya, modul ini diharapkan dapat menjadi salah satu solusi yang dapat digunakan untuk meningkatkan kemampuan guru, terutama yang berkaitan dengan program pendampingan tutorial membaca kepada siswanya.

Modul yang baik merupakan modul yang dibuat sesuai tujuan pembelajaran serta dapat diaplikasikan pada subjek nyata untuk selanjutnya dapat dievaluasi secara empiris. Peneliti selanjutnya yang akan menggunakan modul untuk melakukan percobaan pada subjek hendaknya mengikuti tahapan-tahapan yang telah tertulis sesuai dengan instruksi yang terdapat dalam modul tanpa memberikan penambahan maupun pengurangan materi. 


\section{DAFTAR PUSTAKA}

Ahmad, J., Sulaiman, T., Abdullah, S.K., Shamsuddin, J. (2009). Building a customized module for the treatment of drug addiction under the remedial programs to be implemented on inmates at the drug rehabilitation centers in Malaysia. US-China Education Review, 6, 57-64. Didapat dari http://www.davidpublishing.com/davidpublishing/Upfile/7/9/2012/201207097257496 9.pdf

Arip, M.A.S.M., Bakar, R.B.A., Ahmad, A.B., \& Jais, S.M. (2013). The development of a group guidance module for student self-development based on gestalt theory. Procedia-Social and Behavioral Sciences, 84,1310-1316. doi: 10.1016/j.sbspro.2013.06.748

Ayriza, Y. (2008). Developing and validating the social life skill module for pre-school educator. Jurnal Penelitian dan Evaluasi Pendidikan, volume 2 Tahun XII, hal: 213231. Didapat dari http://download.portalgaruda.org/article.php?article $=102663 \& v a l=448$

Azwar, S. (2012). Reliabilitas dan Validitas. Yogyakarta: Pustaka Pelajar.

Carta, J.J., Greenwood, C.R., Atwater,J., McConnell, S.R., Goldstein, H., \& Kaminski, R.A. (2015). Identifying preschool children for higher tiers of language and early literacy instruction within a response to intervention framework. Journal of Eary Intervention, 36(4), 281-291. doi: 10.1177/1053815115579937.

Gustafson, S., Falth, L., Svensson, I., Tjus, T., \& Heimann,M. (2011). Effects of three interventions on the reading skills of children with reading disabilities in grade 2. Journal of Learning Disabilities, 44, 123-135. doi: 10.1177/0022219410391187.

Hamdani. (2011). Strategi Belajar Mengajar. Bandung: CV Pustaka Setia.

Holman, D., Pavlica, K., \& Thorpe, R. (1997). Rethinking Kolb's theory of experiential learning in management education: The contribution of social construction and activity theory. Journal of Management Learning. 28, 135-148. doi: $10.1177 / 135050769$.

Kumaladewi, N.F. (2011). Pelatihan Keterampilan Membaca Untuk Meningkatkan Kemampuan Pemahaman Membaca Siswa. (Tesis tidak dipublikasikan). Program Magister Profesi Psikologi Fakultas Psikologi Universitas Gadjah Mada, Yogyakarta.

Majid, A. (2013). Strategi Pembelajaran. Bandung: PT Remaja Rosdakarya.

McCarthy, M. (2010). Experiential Learning Theory: From Theory to Practice. Journal of Business and Economic Research,vol.8(5), hal:131-140. Didapat dari http://cluteinstitute.com/ojs/index.php/JBER/article/viewFile/725/710

Ormrod, J.E. (2008). Psikologi Pendidikan Membantu Siswa Tumbuh dan Berkembang jilid 1. Jakarta: Erlangga.

Rozubi, N., Poh Li, L. (2015) The Development of Psychological Well-Being Programme Based on Six Factormodel Psychological Well-Being Ryff. Vol 2, 1176-1180. 
Russel, J. D., \& Johanningsmeier, K. A. (1981). Improving competence through modular instruction. USA: Kendall/Hunt Publishing Company.

Sugiyono. (2015). Metode Penelitian dan Pengembangan (Research and Development/ $R \&$ $D)$. Bandung: Penerbit Alfabeta.

Tomkins, L., \& Ulus, E. (2015). “Oh, was that” experiential learning”'?!' spaces, synergies and surprises with kolb,s learning cycle. Managemen Learning. 1-21. doi: $10.1177 / 1350507615587451$.

Woodcock, S. (2013). Trainee teachers'attitude towards students with spesific learning disabilities. Australian Journal of Teacher Education, 38 (8). Doi: 10/14221/ajte.2013v38n8.6.

Woodcock, S., Vialle, W. (2011). Are we exacerbating students' learning disabilities? An invertigation of preservice teachers' attributions of the educational outcomes of students with learning disabilities. The International Dyslexia Association, 61: 223241. Doi: 10.1007/s11881-011-0058-9.

Woolfolk-Hoy, A., Spero, R. (2005). Changes in teacher efficacy during the early years of teaching: acomparison of four measure. Teaching and teacher Education, 21, 343-356. Didapat dari wps.ablongman.com/wps/...TATE\%202005\%20Spero.pdf 